with particular reference to the effect of changes in regenerator efficiency on the thermal balance sheet. Dr. W. M. Hampton put forward a proposal for a performance figure for glass tank furnaces. While the accurate determination of a thermal balance sheet provides all the information necessary, it involves so much time and work that some simplified method of calculation is anxiously required. It has been the custom in the glass industry to consider the simple ratio glass made/coal used, but it was pointed out that the amount of glass produced in a furnace bears no necessary relation to the amount of glass such a furnace is capable of molting, as commercial considerations frequently come into operation. It is clear that the fuel consumption of a furnace increases with the throughput of glass, and after considering many alternative bases for comparison, it has now been agreed by the Furnace Committee that the fuel consumptions of different furnaces should be compared on the 'no load' basis, that is, the amount of coal needed to maintain the furnace at a given temporature when it is not actually producing any glass. Since the fuel consumption also varies with the temperature at which the furnace is run, Dr. Hampton proposed-and curves were provided to enable the transformation to be carried out simply-that the fuel consumption should be calculated as at a standard temperature of $1400^{\circ} \mathrm{C}$.

It has also now been agreed by the Furnace Committee that the input to the furnace should bo reckoned in heat units instead of in terms of various fuels, and the proposed performance figure suggested as the area of the furnace per unit input of heat which can be maintained at a temperature of $1400^{\circ} \mathrm{C}$. when no glass is being produced. Using the informa. tion collected by the Department of Glass Technology over the last four years on glass tank furnaces in various parts of Great Britain, it was shown that there is a definite correlation between the size of the furmace and its performance figure, and also that the most important factor in improving the performance is adequate insulation. Differences in design are apparently of minor importance.

The general impression left by the meeting and discussion was that the glass industry is fully alive to the necessity for fundamental research, and that by the use of some agreed basis it should be possible to compare the performance of tank furnaces employed in making very widely different types of glass. Such comparisons should enable the effect of variations in design or materials on the performance of furnaces to be estimated, and so lead to substantial improvements in fuel economy.

W. M. HaMpton.

\title{
CIVILIZATIONS IN TRANSITION
}

A LTHOUGH cultural penetrations usually follow predictable lines in accordance with proximity, degree of difference between the civilizations involved, and their relative prestige values, notable exceptions indicate the wide variability of human reactions.

In the symposium on "Civilizations in Transition", held on September 25 as par't of the celebration of the fiftieth anniversary of the University of Chicago, Prof. Robert H. Lowie, professor of anthropology in the University of California, and Prof. Michael I. Rostovtzeff, professor of ancient history in Yale University, discussed phases of cultural infiltration.

Prof. Rostovtzeff, speaking on "The Destinies of Hellenism in the Near East", described the trends toward hegemony and toward subordination which existed simultaneously in the case of the Greek settlers in Egypt. At first the Greeks, bearers of a high culture, were an élite, organizing a complex bureaucracy which virtually undermined the royal power and which milked the native population of its wealth. Later, Prof. Rostovtzeff said, the tendencies towards cultural acclimatization began to take effect, and by the time of the rise of Roman power, the Greek creative force in Egypt had been exhausted.

After the death of Alexander the Great, a wave of Greek emigrants swept into Egypt.

Since the status of the Greeks was that of a privileged class, the higher strata of the native population naturally tried to acquire for themselves this status. The prerequisite for it was Greek education and participation in Greek life. Thus a certain part of the native population became gradually 'Hellenized' and some of them received from the king the status of Hellenes.

Prof. Lowie discussed numerous examples of primitive groups in which cultural transfer depended on such obvious factors as the conqueror-conquered relationship and geographical proximity, but also listed situations in which these factors were outweighed by customs and other cultural phenomena which prevented transfer of traits of civilization when other circumstances were apparently favourable. Speaking on "The Transition of Civilizations in Primitive Societies", he also pointed to societies in which culture spread from the conquered to the conqueror and across apparently insuperable geographical barriers.

Although contact between two cultures usually results in an exchange of cultural traits, it does not always have this result. Dr. Lowie cited as an example four tribes in the Nilgiri Hills of southern India all of which live within easy walking distance of one another. The Toda are buffalo-breeders; the Badaga raise millet; the Kota serve as smiths and musicians; the food-gathering Kurumba practise magic. Transference of traits among the tribes is inhibited by the intense caste sentiment that prevails. When a few Kota attempted to wear turbans, after the fashion of the Badaga, they were at once beaten up by their outraged neighbours. Geographically there is an ideal set-up for a levelling of cultural differences, but any such process is frustrated by the prevailing ideology.

Class consciousness hinders the free spread of ideas by checking one of its most natural promoters, intermarriage; and it is equally potent when material advantages are reserved to a dominant people.

In Ankole, an East African country, the subject Bairu cannot turn into independent stock-breeders so long as their Bahima overlords claim the right to own all productive cows. Another factor preventing exchange of traits is the emotional revulsion to a novelty which, however useful, flouts accepted 
standards, as when Buddhistic scruples prevent the Buddhist from raising silkworms.

Although the raising of edible plants usually spreads rapidly from one culture to another, it is not difficult to find exceptions. Why did rice fail to penetrate Oceania? Why do the contemporary Tahitians, with the example of the Chinese colonist before them, disdain to raise it ? Why did potato cultivation remain confined to Andean cultures in pre-Columbian times even though wild species occurred to the north ? Why did the tomato, a native of South America, reach the Ijca of northern Colombia only in recent times?

Though not all such instances are explainable, Dr. Lowie considers that a partial explanation is that borrowing of cultural traits is not likely to occur when the potential recipient possesses an adequate counterpart.

In discussing the influence of borrowed traits upon culture, Dr. Lowie pointed out that borrowed traits, because of their extreme novelty, seldom are accept. able to the religious aspects of a culture. He cited as examples the reluctance of American Indian tribes to accept horses and guns into their religious ritual and worship, long after both horses and firearms had been widely used by the tribe. The horse remained of little religious importance. Even though it was an object constantly prayed for, we rarely, if ever, hear of a supernatural horse on a par with the bear, eagle, beaver, or other animal spirits. One Crow band had a horse dance, but the celebrants believed that they derived their power from an eagle.

The principle that novelties are religiously inferior holds true for weapons as well. In 1805 the Crow, obliged to obtain firearms and ammunition from the village tribes of the upper Missouri, were still poor shots with the gun. The deficiency was soon overcome, and, what is more, the wresting of a gun in a hand-to-hand fight came to be recognized as an honorific exploit equivalent to the older bowsnatching. Yet in the preparations for the sacred sun dance it was explicitly ordained to shoot a bull without the use of a gun.

Dr. Lowie also referred to the Crow practice of beginning a war expedition on foot, out of respect for the ancient method of fighting, even though the warriors later mounted horses.

Prof. Rostovtzeff stated that while 'Hellenization' was effected among the well-to-do natives, it did not touch the masses of the population of the two monarchies, the peasants of the country and the artisans of the cities, towns, and villages.

In time, the Greeks became privileged servants of the king and soon a powerful bureaucracy grew up dominated by the Greek administrators. From the point of view of the masses, the Greeks were their oppressors. They extracted from them ever heavier taxes, they supervised their compulsory labour, they acted as agents of the Government in exercising an ever stricter control over their economic life. The native working classes complained to their protector, the king, but they soon found out that the kings were helpless to relieve their sufferings. The powerfully organized bureaucracy was stronger than the royal will. No wonder then from time to time the natives rose in revolt.

As the Greeks began to intermarry with Egyptians, Dr. Rostovtzeff declared, they became more and more influenced by Egyptian culture, and soon an 'Orientalized' type of Greek came into existence. The Greeks were gradually absorbed by their Oriental surroundings. Climate, food, environment had their natural effects. A new type was in formation. Wo know little of this type, but its existence is crrtain.

It is significant, for example, how rapidly the Greeks became 'Orientalized' in religion. From the very beginning they worshipped in Fgypt the new 'Hellenized' god Sarapis, a blend of the Egyptian Osiris and certain Greek gods. They became more and more devoted to this god as time went on, and especially to his divine consort the mighty Isis, long familiar to the Greeks. There was also the growing devotion of the Egyptian Greeks to the various animal gods such as the great crocodile god, and to the pseudo-science of astrology.

Another symptom of 'Orientalization' was the gradual change in the spirit of the Greeks. The buoyant energy of the pioneers of the third century B.c., their creative force, gradually subsided. Creation was replaced by routine, the Greek tempo of work was followed by Oriental passivity.

By the time of the rise of Roman power, Dr. Rostovtzeff said, the Greek creative force in Egypt had been exhausted and Egypt and the entire Greek world became incorporated into the Roman Empire.

\section{THE QATTARA DEPRESSION}

\section{By M. G. BEADNELL}

$\mathrm{T}$ HE account in NATURE of November 1 of the career of the late Dr. John Ball, technical adviser to the Geological Survey Department of Egypt, brings vividly before me his enthusiasm on the subject of the Qattara Depression Scheme, with which his name was so closely associated in Egypt.

Roughly speaking, the depression is shaped like an elongat 3 mutton-cutlet, and has a total superficial area of $19,500 \mathrm{sq} . \mathrm{km}$., two thirds of which are more than 50 metres below sea-level, and the remainder reaching a minimum of $-134 \mathrm{~m}$. at a point southeast of the tiny enclosed Oasis of Qara. Its greatest length, from west to east, is $298 \mathrm{~km}$., and greatest breivlth, from north to south, $145 \mathrm{~km}$. The depres- sion extends from nearly $80 \mathrm{~km}$. from Siwa on the west to within $205 \mathrm{~km}$. of Cairo on the east, and its most northerly boundary is only $56 \mathrm{~km}$. from the Mediterranean.

Nearly a third of the floor consists of a damp mixture of sand, clays and salts, known as "Sabakha", an Arabic term applied to deposits having a fertilizing value. (This area is so enormous that a proposal was put forward at the time by a Cairo newspaper that the depression should be exploited for its economic value, as a parallel to that of the Dead Sea, but this was never undertaken.)

The existence of this low-lying tract was discovered only in 1917, and quite fortuitously. The 